\title{
Correlation between Clinical Features and 3 T Mri Findings of Disc Position Status in Patients with Internal Derangement of Temporomandibular Joint
}

\author{
Zeinab Ghadhanfer Hammod \\ Oral Diagnosis Department, College of Dentistry, University of Baghdad.
} Lamia H. Al-Nakib

Oral Diagnosis Department, College of Dentistry, University of Baghdad.

Raad H. Abed Tawfeq

Chairman of the scientific council of the Iraqi medical specialization for Radiodiagnosis.

\begin{abstract}
Background: Internal derangement is defined as an abnormality in the articular disc position and sometimes its' morphology that may interfere with normal function. The aims of study was to correlate between the clinical signs and symptoms and 3 Tesla magnetic resonance imaging findings of the articular disc position in patients with internal derangement of temporomandibular joint. Materials and methods: A total forty six (30 study and 16 control) participants aged between 18 and 49 years, were examined according to Helkimo clinical dysfunction index scoring criteria which include clinical examinations of the range of mandibular mobility, impaired TMJ function, muscle pain ,TMJ pain and pain during mandibular movement.

Results: There is statistically high significant difference between Helkimo clinical dysfunction index in the cases group (with temporomandibular joint disorders) and controls group with MRI findings of disc position, that as the severity of index increased, there were progression of disc displacement and shows positive association expressed by significant probability (p) value.

Conclusion: There is a significant correlation between Helkimos' clinical dysfunction index and MRI findings in patients with internal derangement of temporomandibular joint.
\end{abstract}

KEY WORDS

TMJ,Helkimo index ,3 T MRI.

CITE THIS ARTCLE

Hammod Z,Al-Nakib L,Tawfeq R. Position Status in Patients with Internal Derangement of Temporomandibular Joint. Iraqi Dent. J. 2015; 37(3):119-123. http://www.iraqidentaljournal.com

$$
\begin{aligned}
& \text { العلاقة بين المظاهر السريرية ونتائج التصوير بالرنين المغناطيسي (Tesla 3) لموقع القرص للمرضى الذين } \\
& \text { يعانون من الأضطراب الداخلي للمفصل الفكي الصدغي. }
\end{aligned}
$$

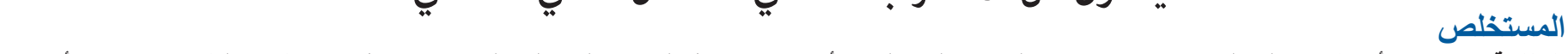

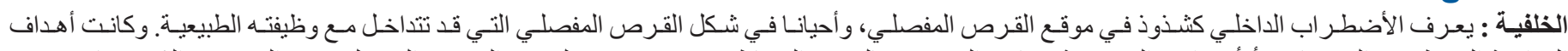

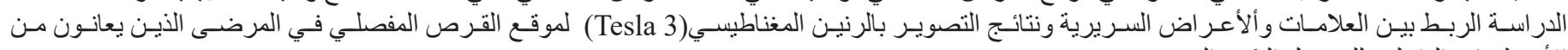

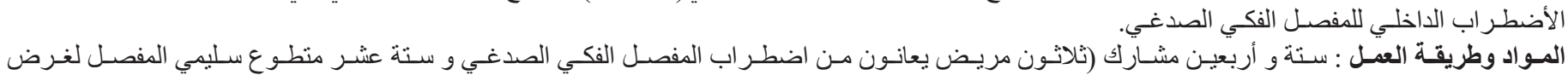

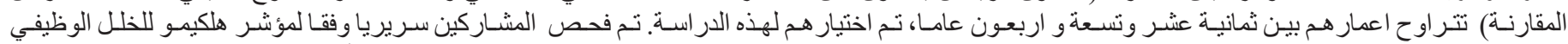

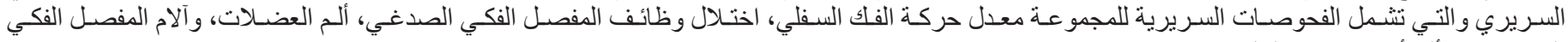

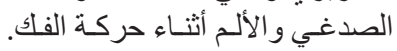

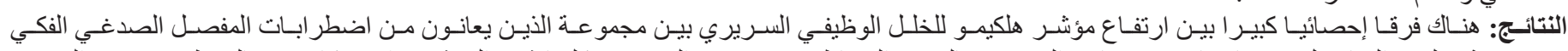

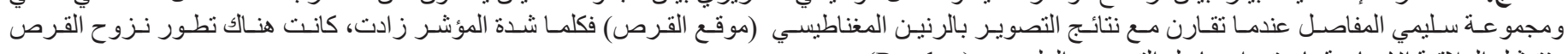

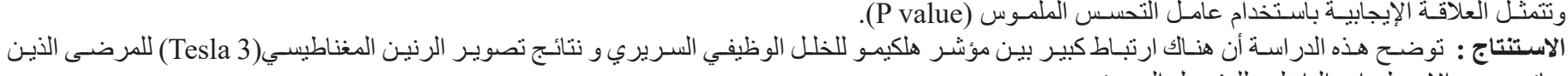

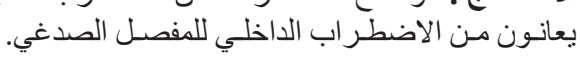

\section{INTRODUCTION}

The definition of internal derangement is a mechanical fault of the joint which interferes with smooth joint function that is attributed to abnormal interaction like condyle and articular eminence of the articular disc, the clinical features that is included with internal derangement is articular pain and articular noises as discussed by Rudisch et al. ${ }^{(1)}$. The disc displacement is categorized based on the relation of the disc displacement with mandibular condyle. The displacement can be anterior, anterolateral, anteromedial, lateral, medial and posterior ${ }^{(2)}$.Magnetic resonance imaging (MRI) of the temporomandibular joint has resulted in better understanding of the TMJ and better comprehension of its disorders. MRI can provide positional information about the disc location, information about the status of the quality of retrodiscal tissue; lateral pterygoid muscle and condition of the bone marrow ${ }^{(3)}$.

\section{MATERIALS AND METHODS}

A prospective study was conducted on 46 patients attending Oral and Maxillofacial Surgery Department in AL- Yarmouk Teaching Hospital that were referred to clinic of Radiology for MRI from over the period 
of 5 months (September 2014 - February,2015). The patients were selected and divided into two groups:

1.Case group thirty patients (18-49) years old (22 females and 8 males) were clinically diagnosed as having internal derangements of temporomandibular joint. All patients were complained from pain in preauricular area and muscles of mastication ,clicking or crepitation of TMJ, a limitation or deviation in mandibular range of motion, they were again grouped according to severity.

2.Control group sixteen participants (18-46) years old (10 females and six males) with normal TMJs.

The patients examined according to Helkimo clinical dysfunction index scoring criteria of temporomandibular disorders which consists of standardized series of diagnostic tests based on clinical signs and symptoms as the following:

1.Determination of the mouth opening without pain and the mouth opening with pain (un-assisted mouth opening). This accomplished by measuring the inter-incisal distance plus the overbite when the patient opens his mouth as wide as he could. A general guide for minimum normal mouth opening is $45 \mathrm{~mm}$ including the overbite.

2.Palpation the TMJ during opening and closing three times at least to detect the joint sound. clicking,cripitation,luxattion or deviation of TMJ.

3.Determination of masticatory muscles and TMJ pain during excursive movement of mandible. Determination of the tender points of muscles by palpating muscles bilaterally the Temporalis Muscle, Masseter Muscle, Medial pterygoid muscle, Lateral pterygoid muscle, Posterior digastric muscle and Sternocleidomastoid muscle.

4.Examination of TMJ pain and tenderness was done by digital palpating of the joint performed from both lateral and posterior aspect, the finger tips were placed over the lateral aspect of both joints simultaneously while the posterior aspect was reached via the external auditory meatus by small finger forced anteriorly. The patient was instructed to do movement of opening, closing, laterotrusion to the right and left and protrusion, and then asked if he experienced pain in one movement or more.

MRI was carried out with MRI 3.0 Tesla, Achieva Philips Medical System Nederland B.V. with standard head coil , the patient in a supine position. Bite block were used during open mouth position. The data were collected on $256 \times 256$ matrix giving a pixel size of $0.60 \times 0.57 \mathrm{~mm}$. Proton Density (PD) pblique Sagittal (closed and opened mouth). (TR) $=528$ miliseconds , $(\mathrm{TE})=13 \mathrm{~ms},(\mathrm{FOV})=150 \mathrm{~mm}$, flip angle $=90^{\circ}$, number of slices $=22$ slice and slice thickness $=2.0$ $\mathrm{mm}$.

\section{RESULTS}

Significant differences in correlation between mobility index total score of Helkimo clinical dysfunction index and MRI findings of TMJ disc displacement types. $(\mathrm{P}<0.001)$ means a very high significant differences in correlation between mobility index total score and the normal TMJ disc, the highest value $84.2 \%$ at a negative (zero score), while lowest value $5.3 \%$ the at a high grade (score 5).In anterior disc displacement with reduction, the highest value $74.2 \%$ at a low grade (score 1), while the lowest value $0.0 \%$ at negative (zero score). Anterior disc displacement without reduction the highest value $59.1 \%$ at a high grade (score 5), while the lowest value $0.0 \%$ at a negative (zero score) (Table 1). Significant differences in correlation between impaired TMJ function total score of Helkimo clinical dysfunction index and MRI findings of TMJ disc displacement types. $(\mathrm{P}<0.001)$ means a very high significant differences in correlation between impaired TMJ function total score and normal (Not displaced), the highest value $97.4 \%$ at a negative (score zero), while the lowest value $0.0 \%$ the at a high grade (score 5). Anterior disc displacement with reduction, the highest value $96.8 \%$ at a low grade (score 1), while the lowest value $0.0 \%$ at a high grade (score 5). Anterior disc displacement without reduction, the highest value $54.5 \%$ at a high grade (score 5), the lowest value $0.0 \%$ at a negative (score zero) (Table 2).

Significant differences in correlation between muscle tenderness total score of Helkimo clinical dysfunction index and MRI findings of TMJ disc displacement types. $(\mathrm{P}<0.001)$ means a very high significant differences in correlation between muscle tenderness total score and normal (Not displaced), the highest value $86.8 \%$ at a negative (score zero), while the lowest value $2.6 \%$ at a high grade (score 5). Anterior disc displacement with reduction, the highest value $61.3 \%$ at a low grade (score 1), while the lowest value $0.0 \%$ at a negative (score zero). Anterior disc displacement without reduction, the highest value $59.1 \%$ at a high grade (score 5), while the lowest value $4.5 \%$ at a negative (score zero) (Table 3).Significant differences in correlation between TMJ tenderness total score of Helkimo clinical dysfunction index and MRI findings of TMJ disc displacement types. $(\mathrm{P}<0.001)$ means a very high significant differences in correlation between TMJ tenderness total score and normal (Not displaced), the 
highest value $100 \%$ at a negative (score zero) while the lowest value $0.0 \%$ at a low grade (score 1), at a high grade (score 5). Anterior disc displacement with reduction, the highest value $51.6 \%$ at a low grade (score 1), while the lowest value $19.4 \%$ at a high grade (score 5). Anterior disc displacement without reduction, the highest value $63.6 \%$ at a high grade (score 5), the lowest value $4.5 \%$ at a negative (score zero) (Table 4).Significant differences in correlation between pain on mandibular movement total score of Helkimo clinical dysfunction index and MRI findings of TMJ disc displacement types. $(\mathrm{P}<0.001)$ means a very high significant differences in correlation between pain on mandibular movement total score and normal (Not displaced), the highest value $97.4 \%$ at a negative (score zero), while the lowest value $0.0 . \%$ at a high grade (score 5). Anterior disc displacement with reduction, the highest value 80.6 $\%$ at a low grade (score 1), while the lowest value $9.7 \%$ at a negative (score zero), a high grade (score 5). Anterior disc displacement without reduction, the highest value $63.6 \%$ at a high grade (score 5), while the lowest value $4.5 \%$ at a negative (score zero) (Table 5).

Table 1: Correlation between mobility index total score of Helkimo clinical dysfunction index and MRI findings of TMJ disc displacement types.

\begin{tabular}{|c|c|c|c|c|c|c|c|c|c|c|c|}
\hline \multirow{3}{*}{ Type of disc displacement } & \multicolumn{8}{|c|}{ Mobility index total score } & \multirow{3}{*}{ Median } & \multirow{3}{*}{$\begin{array}{c}\text { Mean } \\
\text { rank }\end{array}$} & \multirow{3}{*}{$\boldsymbol{P}$} \\
\hline & \multicolumn{2}{|c|}{$\begin{array}{l}\text { Negative } \\
\text { (score zero) }\end{array}$} & \multicolumn{2}{|c|}{$\begin{array}{l}\text { Low grade } \\
\text { (score 1) }\end{array}$} & \multicolumn{2}{|c|}{$\begin{array}{l}\text { High grade } \\
\text { (score } 5 \text { ) }\end{array}$} & \multicolumn{2}{|c|}{ Total } & & & \\
\hline & $N$ & $\%$ & $N$ & $\%$ & $N$ & $\%$ & $N$ & $\%$ & & & \\
\hline Normal & 32 & 84.2 & 4 & 10.5 & 2 & 5.3 & 38 & 100.0 & $\begin{array}{l}\text { Negative } \\
\text { (score zero) }\end{array}$ & 23.4 & \\
\hline $\begin{array}{l}\text { Anterior disc displacement } \\
\text { with reduction }\end{array}$ & 0 & 0.0 & 23 & 74.2 & 8 & 25.8 & 31 & 100.0 & $\begin{array}{l}\text { Low grade } \\
\text { (score } 1)\end{array}$ & 58.1 & $<0.001$ \\
\hline $\begin{array}{l}\text { Anterior disc displacement } \\
\text { without reduction }\end{array}$ & 0 & 0.0 & 9 & 40.9 & 13 & 59.1 & 22 & 100.0 & $\begin{array}{l}\text { High grade } \\
\text { (score 5) }\end{array}$ & 67.9 & \\
\hline
\end{tabular}

Table (2): Correlation between impaired TMJ function total score of Helkimo clinical dysfunction index and MRI findings of TMJ disc displacement types.

\begin{tabular}{|c|c|c|c|c|c|c|c|c|c|c|c|}
\hline \multirow{3}{*}{ Type of disc displacement } & \multicolumn{8}{|c|}{ Impaired TMJ function total score } & \multirow{3}{*}{ Median } & \multirow{3}{*}{$\begin{array}{c}\text { Mean } \\
\text { rank }\end{array}$} & \multirow{3}{*}{$\boldsymbol{P}$} \\
\hline & \multicolumn{2}{|c|}{$\begin{array}{c}\text { Negative } \\
\text { (score zero) }\end{array}$} & \multicolumn{2}{|c|}{$\begin{array}{l}\text { Low grade } \\
\text { (score 1) }\end{array}$} & \multicolumn{2}{|c|}{$\begin{array}{c}\text { High } \\
\text { grade } \\
\text { (score 5) }\end{array}$} & \multicolumn{2}{|c|}{ Total } & & & \\
\hline & $N$ & $\%$ & $N$ & $\%$ & $N$ & $\%$ & $N$ & $\%$ & & & \\
\hline Normal & 37 & 97.4 & 1 & 2.6 & 0 & 0.0 & 38 & 100.0 & $\begin{array}{l}\text { Negative } \\
\text { (score zero) }\end{array}$ & 20.5 & \\
\hline $\begin{array}{l}\text { Anterior disc displacement } \\
\text { with reduction }\end{array}$ & 1 & 3.2 & 30 & 96.8 & 0 & 0.0 & 31 & 100.0 & $\begin{array}{l}\text { Low grade } \\
\text { (score 1) }\end{array}$ & 57.7 & $<0.001$ \\
\hline $\begin{array}{l}\text { Anterior disc displacement } \\
\text { without reduction }\end{array}$ & 0 & 0.0 & 10 & 45.5 & 12 & 54.5 & 22 & 100.0 & $\begin{array}{l}\text { High grade } \\
\text { (score 5) }\end{array}$ & 73.5 & \\
\hline
\end{tabular}

Table (3): Correlation between muscle tenderness total score of Helkimo clinical dysfunction index and MRI findings of TMJ disc displacement types.

\begin{tabular}{|c|c|c|c|c|c|c|c|c|c|c|c|}
\hline \multirow{3}{*}{ Type of disc displacement } & \multicolumn{8}{|c|}{ Muscle tenderness total score } & \multirow{3}{*}{ Median } & \multirow{3}{*}{$\begin{array}{c}\text { Mean } \\
\text { rank }\end{array}$} & \multirow{3}{*}{$\boldsymbol{P}$} \\
\hline & \multicolumn{2}{|c|}{$\begin{array}{l}\text { Negative } \\
\text { (score zero) }\end{array}$} & \multicolumn{2}{|c|}{$\begin{array}{c}\text { Low grade } \\
\text { (score 1) }\end{array}$} & \multicolumn{2}{|c|}{$\begin{array}{c}\text { High } \\
\text { grade } \\
\text { (score 5) }\end{array}$} & \multicolumn{2}{|c|}{ Total } & & & \\
\hline & $N$ & $\%$ & $N$ & $\%$ & $N$ & $\%$ & $N$ & $\%$ & & & \\
\hline Normal & 33 & 86.8 & 4 & 10.5 & 1 & 2.6 & 38 & 100.0 & $\begin{array}{l}\text { Negative } \\
\text { (score zero) }\end{array}$ & 22.5 & $<0.001$ \\
\hline $\begin{array}{l}\text { Anterior disc displacement } \\
\text { with reduction }\end{array}$ & 0 & 0.0 & 19 & 61.3 & 12 & 38.7 & 31 & 100.0 & $\begin{array}{l}\text { Low grade } \\
\text { (score } 1)\end{array}$ & 61 & \\
\hline
\end{tabular}




\section{Orthodontics}

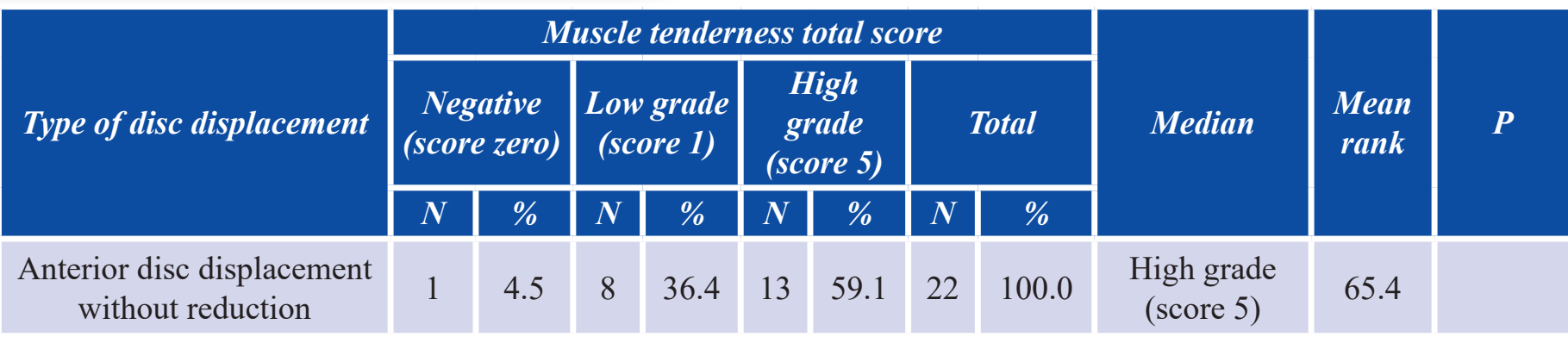

Table (4): Correlation between TMJ tenderness total score of Helkimo clinical dysfunction index and MRI findings of TMJ disc displacement types.

\begin{tabular}{|c|c|c|c|c|c|c|c|c|c|c|c|}
\hline \multirow{3}{*}{ Type of disc displacement } & \multicolumn{8}{|c|}{ TMJ tenderness total score } & \multirow{3}{*}{ Median } & \multirow{3}{*}{$\begin{array}{c}\text { Mean } \\
\text { rank }\end{array}$} & \multirow{3}{*}{$\boldsymbol{P}$} \\
\hline & \multicolumn{2}{|c|}{$\begin{array}{c}\text { Negative } \\
\text { (score } \\
\text { zero) }\end{array}$} & \multicolumn{2}{|c|}{$\begin{array}{c}\text { Low } \\
\text { grade } \\
\text { (score 1) }\end{array}$} & \multicolumn{2}{|c|}{$\begin{array}{c}\text { High } \\
\text { grade } \\
\text { (score 5) }\end{array}$} & \multicolumn{2}{|c|}{ Total } & & & \\
\hline & $N$ & $\%$ & $N$ & $\%$ & $N$ & $\%$ & $\mathbf{N}$ & $\%$ & & & \\
\hline Normal & 38 & 100.0 & 0 & 0.0 & 0 & 0.0 & 38 & 100.0 & $\begin{array}{l}\text { Negative } \\
\text { (score zero) }\end{array}$ & 24.5 & \\
\hline $\begin{array}{l}\text { Anterior disc displacement with } \\
\text { reduction }\end{array}$ & 9 & 29.0 & 16 & 51.6 & 6 & 19.4 & 31 & 100.0 & $\begin{array}{l}\text { Low grade } \\
\text { (score 1) }\end{array}$ & 53.9 & $<0.001$ \\
\hline $\begin{array}{l}\text { Anterior disc displacement } \\
\text { without reduction }\end{array}$ & 1 & 4.5 & 7 & 31.8 & 14 & 63.6 & 22 & 100.0 & $\begin{array}{l}\text { High grade } \\
\text { (score 5) }\end{array}$ & 72.1 & \\
\hline
\end{tabular}

Table (5): Correlation between pain on mandibular movement total score of Helkimo clinical dysfunction index and MRI findings of TMJ disc displacement types.

\begin{tabular}{|c|c|c|c|c|c|c|c|c|c|c|c|}
\hline \multirow{3}{*}{ Type of disc displacement } & \multicolumn{8}{|c|}{ Pain on mandibular movement total score } & \multirow{3}{*}{ Median } & \multirow{3}{*}{$\begin{array}{l}\text { Mean } \\
\text { rank }\end{array}$} & \multirow{3}{*}{$\boldsymbol{P}$} \\
\hline & \multicolumn{2}{|c|}{$\begin{array}{l}\text { Negative } \\
\text { (score zero) }\end{array}$} & \multicolumn{2}{|c|}{$\begin{array}{l}\text { Low grade } \\
\text { (score 1) }\end{array}$} & \multicolumn{2}{|c|}{$\begin{array}{c}\text { High } \\
\text { grade } \\
\text { (score 5) }\end{array}$} & \multicolumn{2}{|c|}{ Total } & & & \\
\hline & $N$ & $\%$ & $N$ & $\%$ & $N$ & $\%$ & $N$ & $\%$ & & & \\
\hline Normal & 37 & 97.4 & 1 & 2.6 & 0 & 0.0 & 38 & 100.0 & $\begin{array}{l}\text { Negative } \\
\text { (score zero) }\end{array}$ & 22 & $<0.001$ \\
\hline $\begin{array}{l}\text { Anterior disc displacement } \\
\text { with reduction }\end{array}$ & 3 & 9.7 & 25 & 80.6 & 3 & 9.7 & 31 & 100.0 & $\begin{array}{l}\text { Low grade } \\
\text { (score } 1)\end{array}$ & 56.8 & \\
\hline $\begin{array}{l}\text { Anterior disc displacement } \\
\text { without reduction }\end{array}$ & 1 & 4.5 & 7 & 31.8 & 14 & 63.6 & 22 & 100.0 & $\begin{array}{l}\text { High grade } \\
\text { (score } 5)\end{array}$ & 72.2 & \\
\hline
\end{tabular}

\section{DISCUSSION}

In present study the correlation analysis between mobility index total score of Helkimo clinical dysfunction index and MRI findings of TMJ disc displacement types, these findings were in agreement with that reported by Saeed ${ }^{(4)}$; Aidar et al.(5); Hasan and Abdelrahman ${ }^{(6)}$.Limitation of condylar translation in open mouth was observed in this series only in joints with anterior disc displacement and significantly more frequent in cases of compete anterior disc displacement without reduction followed by compete anterior disc displacement with reduction, which could be explained as the anteriorly positioned disc may act as a mechanical interference to the anterior translation of the condyle to its normal position at the apex of the articular eminence in open mouth.
A previous study assessed the degree of mandibular mobility in patients with a clinical diagnosis of temporomandibular disorder and healthy individuals and found a significant difference in the groups of patients with muscle disorders and anterior disc displacement with reduction regarding mandibular mobility when compared with the control group ${ }^{(6)}$. Range of movement is the most evident expression of joint function ${ }^{(7)}$, and its limitation may be caused by disc displacement ${ }^{(8)}$. In our study, 13 patients already had disc displacement at $\mathrm{T}_{1}$, and only patient 13 had limited movements (lower than $7 \mathrm{~mm}$ ). Patient 1, who had a well-positioned joint disc at $\mathrm{T}_{1}, \mathrm{~T}_{3}$ and $\mathrm{T}_{4}$ had disc displacement according to both MRIs, a likely sign of dysfunction ${ }^{(5)}$. A very high significant differences in correlation between impaired TMJ 


\section{Orthodontics}

function total score and anterior disc displacement with reduction, these findings were in agreement with that reported by Güler et al. ${ }^{(9)}$; Bisi et al. ${ }^{(10)}$. These findings were in disagreement with that reported by Westesson et al. ${ }^{(11)}$;Saeed ${ }^{(4)}$ because of a disc displacement does not necessarily cause functional abnormalities such as limited mouth opening or clicking. Disc displacements are defined as abnormal positions of the articular disc against the condyle and the TMJ articular eminence. The disorder has been linked to pain, articular sounds and limited mouth opening ${ }^{(12)}$. A very high significant differences in correlation between muscle tenderness total score and anterior disc displacement with reduction, these findings were in agreement with that reported by Taskaya-Y1lmaz, and Ogutcen- Toller (13); Saeed ${ }^{(4)}$ ; Aidar et al. ${ }^{(5)}$;Kassab et al. ${ }^{(14)}$. Continuous muscle activity could be provoked by displacement of the TMJ disc and ceased when the disc was returned to a normal position on opening mouth only to recur every time the disc became displaced on closure of mouth. Anterior disc displacement without reduction (closed lock) could cause spastic activity in the temporalis muscle on the affected side. Spastic activity of the masseter and temporalis muscles on the same side as a joint with anterior disc displacement hinders the condylar movement necessary to achieve reduction (15). Avery high significant differences in correlation between TMJ tenderness total score and anterior disc displacement without reduction. In a recent study by Emshoff et al. ${ }^{(16)}$,the MR findings most associated with TMJ pain were anterior disc displacement without reduction and the presence of bone marrow edema.Lamot et al. ${ }^{(17)}$ revealed that "The effect of disc displacement on the presence of symptoms in our patients was most evident in the group with anterior disc displacement without reduction. On the basis of a high probability of developing pain in this group (OR of 26 for right TMJ, 31.92 for left TMJ), we conclude that anterior disc displacement without reduction can be considered to be an important cause of pain. On the other hand, we found only a marginal correlation between anterior disc displacement with reduction and symptoms. Symptoms in these patients were probably a result of changes in synovial, bone and ligamentous structures of the TMJ".

\section{REFERENCES}

1. Rudisch A, Innerhofer K, Bertram S, Emshoff R .Magnetic resonance imaging findings of internal derangement and effusion in patients with unilateral temporomandibular joint pain. Oral Surg Oral Med Oral Pathol Oral Radiol Endod. Nov 2001; 92(5):566-71.

2. Tasaki MM, Westesson P-L, Isberg,AM, Yan-Fang R, Tallents RH.Classification and prevalence of temporomandibular joint disk displacement in patients and symptom-free volunteers. Am J Orthod Dentofac Orthop. 1996; 109:249.

3. Adame Carlos Goizuela, Monje Florencio , Munoz Mario.et.al. Effusion in Magnetic Resonance Imaging of the Tempromandibular Joint. j.Oral Maxillofacial surg. 1998;56,314-318.

4. Saeed Shahrazaad Sami .Correlation between Clinical Features \& MRI Findings in Patients with Internal Derangement of Temporomandibular Joint. unpublished M.Sc. Thesis, College of Dentistry, University of Baghdad. 2005.

5. Aidar uís Antônio de Arruda, Abrahão Márcio Yamashita, Hélio K., Dominguez Gladys Cristina. Morphological Changes of Condyles and Helkimo Clinical Dysfunction Index in Patients Treated with Herbst - Orthodontic Appliance. Braz. Dent. J. July/Aug. 2013; vol.24 no.4 :31321.

6. Hasan Nahla Mohamed Ali , Abdelrahman Tarek Elsayed Ftohy. MRI evaluation of TMJ internal derangement: Degree of anterior disc displacement correlated with other TMJ soft tissue and osseous Abnormalities. The Egyptian Journal of Radiology and Nuclear Medicine .2014; 45, $735-744$

7. Slavicek R. Clinical and instrumental functional analysis for diagnosis and treatment plannind. J Clin Orthod 1988;XXII:498-508.

8. Ribeiro RF, Tallents RH, Katzberg RW, Murphy WC, Moss ME,Magalhaes AC et al. The prevalence of disc displacement in symptomatic and asymptomatic volunteers aged 6 to 25 years. J Orofacial Pain: 1997; 11:37.

9. Güler N, Yatmaz PI, Ataoglu H, Emlik D, Uckan S.Temporomandibular internal derangement: correlation of MRI findings with clinical symptoms of pain and joint sounds in patients with bruxing behaviour. Dentomaxillofac Radiol. 2003 Sep; 32(5):304-10.

10. Bisi Maurício André, Chaves Karen Dantur Batista, Puricelli Edela, Ponzoni Deise, Martins Eleutério Araújo . Relationship between sounds and disc displacement of the temporomandibularjoint using magnetic resonance imaging. Original Article. Rev. odonto ciênc. 2010;25(1):37-41.

11. Westesson P.L., Eriksson L., K. Kurita.Reliability of a negative clinical temporomandibular joint examination: prevalence of disk displacement in asymptomatic temporomandibular joints. Oral Surg Oral Med Oral Pathol, 1989; 68 ,pp. 551-554

12. Emshoff R, Innerhofer K, Rudisch A, Bertram S. Clinical versus magnetic resonance imaging findings with internal derangement of the temporomandibular joint: an evaluation of anterior disc displacement without reduction. J Oral Maxillofac Surg 2002;60:36-41.

13. Taskaya-Yilmaz N, Ogutcen-Toller M. Magnetic resonance imaging evaluation of temporomandibular joint disc deformities in relation to type of disc displacement. J Oral Maxillofac Surg.2001; 59(8),860-865.

14. Kassab Mohamed, bakry Ahmed, Salem Walid Samir. The incidence of temporomandibular joint disorders among 